\title{
MICRONUTRIENTS DEFICIENCY ON THE NUTRITIONAL STATUS OF BANANA PRATA SEEDLINGS ${ }^{1}$
}

\author{
BRUNA PEREIRA DE SOUZA², ENILSON DE BARROS SILVA ${ }^{3}$, \\ MARIA DO CÉU MONTEIRO DA CRUZ ${ }^{4}$, EDSON PERITO AMORIM ${ }^{5}$, \\ SÉRGIO LUIZ RODRIGUES DONATO ${ }^{6}$
}

ABSTRACT - The knowledge of the requirements and micronutrients efficiency in banana is relevant to the development of fertilizer recommendations. This study aimed to evaluated requirements and nutritional efficiencies of banana seedlings submitted to omission of micronutrients in nutritive solution. Treatments were complete nutritive solution and solution with individual omission of $\mathrm{B}, \mathrm{Cu}, \mathrm{Fe}, \mathrm{Mn}$ and $\mathrm{Zn}$, and two Prata-Anã and BRS Platina hybrid genotypes. Leaf area, dry matter of leaves, rhizome, roots and total and micronutrient contents were determined. With results, the following indexes were calculated: uptake, transport and micronutrient utilization efficiency. B deficiency effected more intensely the growth of both banana genotypes. The nutrient uptake corresponded to the following sequence: $\mathrm{Fe}>\mathrm{Mn}>\mathrm{Zn}>\mathrm{B}>\mathrm{Cu}$, which reflects the plant requirements. The BRS Platina hybrid showed higher B, Fe and $\mathrm{Zn}$ absorption efficiency in relation to Prata Anã cultivar, which had higher $\mathrm{Cu}$ absorption efficiency. BRS Platina hybrid showed higher efficiency in the transport of $\mathrm{Fe}$ and $\mathrm{Mn}$, while Prata Anã only for $\mathrm{Cu}$. Prata Anã cultivar showed higher micronutrient utilization efficiency in complete treatment and treatment with omission of micronutrients.

Index terms: Musa spp.; mineral nutritional; micronutrient omission; fruit trees.

\section{DEFICIÊNCIAS DE MICRONUTRIENTES NO ESTADO NUTRICIONAL DE MUDAS DE BANANEIRA PRATA}

\begin{abstract}
RESUMO - O conhecimento das exigências e eficiências nutricionais de micronutrientes em cultivares de bananeira é relevante para o desenvolvimento da recomendação de adubação para esta cultura. Objetivou-se avaliar as exigências e eficiências nutricionais de mudas de bananeira Prata submetidas à omissão de micronutrientes em solução nutritiva. Os tratamentos foram solução nutritiva completa e solução com omissão individual de $\mathrm{B}, \mathrm{Cu}, \mathrm{Fe}, \mathrm{Mn}$ e $\mathrm{Zn}$ e dois genótipos, Prata-Anã e seu híbrido BRS Platina. Determinou-se a área foliar, a massa de matéria seca das folhas, rizoma, raízes e total e o teor de micronutrientes nos respectivos órgãos. Com esses resultados calcularam-se os índices: eficiência de absorção, de transporte e de utilização dos micronutrientes. A deficiência de B foi a que afetou mais intensamente o crescimento dos dois genótipos de bananeira. $\mathrm{O}$ acúmulo de nutrientes correspondeu à seguinte ordem, $\mathrm{Fe}>\mathrm{Mn}>\mathrm{Zn}>$ $\mathrm{B}>\mathrm{Cu}$, o que reflete as exigências da planta. O híbrido BRS Platina apresentou maior eficiência de absorção do B, Fe e $\mathrm{Zn}$ em relação a cultivar Prata Anã que teve maior eficiência na absorção de $\mathrm{Cu}$. O híbrido BRS Platina apresentou maior eficiência de transporte de $\mathrm{Fe}$ e Mn enquanto a Prata-Anã somente para o $\mathrm{Cu}$. A cultivar Prata Anã apresentou maior eficiência de utilização dos micronutrientes no tratamento completo e no tratamento com omissão dos micronutrientes. Termos para indexação: Musa spp.; nutrição mineral; omissão de micronutrientes; frutíferas.
\end{abstract}

\footnotetext{
'(Trabalho 120-15). Recebido em: 08-03-2015. Aceito para publicação em: 18-11-2015.

${ }^{2}$ Engenheira Agrônoma, Mestrando do Programa de Pós-Graduação em Fitotecnia. Universidade Federal de Viçosa (UFV). ViçosaMG. E-mail: bruna_pereiradesouza@yahoo.com

${ }^{3}$ Engenheiro Agrônomo, Dr., Professor Associado, Universidade Federal do s Vales do Jequitinhonha e Mucuri (UFVJM). DiamantinaMG. E-mail: ebsilva@ufvm.edu.br

${ }^{4}$ Engenheira Agrônoma, Dra., Professora Adjunta, UFVJM. E-mail: m_mariceu@yahoo.com.br

${ }^{5}$ Engenheiro Agrônomo, Dr., Pesquisador, Embrapa Mandioca e Fruticultura Tropical. Cruz das Almas-BA. E-mail: edson@cnpmf. embrapa.br

${ }^{6}$ Engenheiro Agrônomo, Dr., Professor, Instituto Federal de Educação Ciência e Tecnologia Baiano. Guanambi-BA. E-mail: sergiodonatoeaf@yahoo.com.br
} 


\section{INTRODUCTION}

Banana (Musa spp) is among the most commercially exploited fruits, being one of the fruits most consumed worldwide. Brazil is the world's second largest producer, with production of 6.86 million tons, also standing out as the largest consumer (IBGE, 2012).

The growth and development of banana are affected by several factors, among them nutrition, which is decisive for plants to reach high yields, since they have rapid growth and accumulate large amounts of nutrients (Hoffmann et al, 2010; Rodrigues et al., 2010). The nutritional requirements of seedlings and the nutritional efficacy of new cultivars should be considered, which differentiate to a greater or lesser response to certain nutrients, consequently influencing dry matter production.

The alternative to assess the nutritional requirements of crops is through the subtraction diagnostic technique. This technique involves growing plants under field or greenhouse conditions hydroponically, in which a complete treatment is tested (with all necessary nutrients in appropriate doses) and a number of treatments, in which the omission of each nutrient is made separately. However, studies in field conditions do not allow to accurately assess the nutrient use efficiency on the physiology and growth of plants.

The lack or excess of a given nutrient can cause similar symptoms in different plant species due to the similarity of roles that they play in plant physiology. Differentiated effects are common among and within the same species as a result of gene expression influenced by the deficiency or toxicity of nutrients (MAATHUIS; DIATLOFF, 2013).

The terminology 'nutritional efficiency' is used to characterize the ability of plants to absorb, translocate and use nutrients under conditions of low availability in soil (KHOSHGOFTARMANESH et al, 2010; SADEGHZADEH et al, 2013.). For this reason, the mechanisms related to the acquisition and utilization of nutrients should be interpreted properly so that mistakes in relation to increased productivity of crops are not made (CHRISTO et al, 2014; MARTINS et al, 2015).

The concept of nutrient use efficient includes processes in which plants absorb, translocate, accumulate and use nutrients for dry matter or grain production under normal or adverse conditions (POZZA et al., 2009). Thus, new banana cultivars may have different nutritional requirements and efficiencies; with greater or lesser response to certain nutrients and therefore influence nutrient conversion in the dry matter mass production.

In this context, this study aimed to evaluate the requirements and nutritional efficiency of banana seedlings Prata Anã and BRS Platina hybrid cultivars submitted to the omission of micronutrients in the nutrient solution.

\section{MATERIAL AND METHODS}

The experiment was conducted in greenhouse located at the JK Campus, Department of Agronomy - University of Vales do Jequitinhonha and Mucuri (UFVJM), Diamantina, Brazil, from August to December 2010. The experimental design was completely randomized with four replicates and one plant per pot. Treatments consisted of complete nutrient solution (macro and micronutrients) and solution with the omission of one micronutrient at a time (-Cu, $-\mathrm{Fe},-\mathrm{Mn},-\mathrm{B}$ and $-\mathrm{Zn})$ and two genotypes, Prata Anã and its BRS Platina hybrid.

The nutrient solution used was proposed by Hoagland and Arnon (1950) and nutrients supplied were derived from reagents. The complete solution had the following chemical composition in macronutrients $\left(\mathrm{mg} \mathrm{L}^{-1}\right): 210.1$ of $\mathrm{N}, 31$ of $\mathrm{P}$, 234.6 of K, 200.4 of Ca, 48.6 of Mg, 64.2 of S, and micronutrients $\left(\mu \mathrm{g} \mathrm{L}^{-1}\right)$ : 500 of B, 20 of $\mathrm{Cu}, 648$ of $\mathrm{Cl}, 5.022$ of Fe, 502 of $\mathrm{Mn}, 11$ of Mo and 50 of $\mathrm{Zn}$. Treatments with omission of micronutrients used the same solution featuring all the nutrients, except for the missing element.

Plantlets of banana genotypes (Prata Anã and BRS Platina hybrid) were provided by Embrapa Mandioca e Fruticultura Tropical of Cruz das Almas (BA). Seedlings were kept for three days in solution with $1 / 4$, then for three days in solution with $1 / 2$ the concentration recommended by the authors, with continuous artificial aeration system using air compressor. After the adaptation period, in which the solution consisted only of macronutrients, plantlets were transferred to plastic pots with constant aeration system and containing $3 \mathrm{~L}$ of nutrient solution 100\% of the ionic strength. The volume of solutions in pots was daily monitored, and when necessary, the volume absorbed by plants was completed with deionized water, and solutions were replaced fortnightly. The $\mathrm{pH}$ of the nutrient solution was maintained at about $6.0 \pm 0.1$; applying $\mathrm{HCl} 0.1 \mathrm{~mol} \mathrm{~L}^{-1}$ or $\mathrm{NaOH} 1.0 \mathrm{~mol}$ $\mathrm{L}^{-1}$ with daily control, as needed, using a portable $\mathrm{pH}$ meter. The electrical conductivity of the nutrient solution was not monitored.

At 100 days after the start of the experimental period, seedlings were collected and divided into 
roots, rhizomes and leaves. Leaves were scanned using an HP Photosmart C3180 Multifunction printer to determine leaf area (LA) using the DDA software (Digital Determinator of Areas) (Ferreira et al., 2008). Then, the plant material was washed in distilled water, labeled, packaged in paper bags and dried in an oven with air circulation at temperature of $65^{\circ} \mathrm{C}$ for $96 \mathrm{~h}$ until constant weight is obtained. After drying, the material was weighed on an analytical scale to obtain the dry weight of rhizome (MSRI), leaves (MSF), aerial parts (leaves and rhizome) (MSPA), roots (MSR) and total (MSTO). Subsequently, the material was ground and submitted to chemical analysis to determine the micronutrient levels according to the methodology described by Silva (2009).

With the content of micronutrients and dry matter of the different organs, the following indexes were calculated: absorption efficiency $=$ (total nutrient content in the plant) / (dry matter of roots) as Swiader et al. (1994); transport efficiency $=($ content of nutrient in the shoot / overall content of nutrient in the plant) $\times 100$, according to Li et al. (1991) and use efficiency $=(\text { total dry matter produced })^{2} /($ total content of nutrient in the plant), according to Siddqi and Glass (1981).

To calculate the relative growth $(\mathrm{RG})$ of total dry matter of banana genotypes, the following formula was used: $\mathrm{RG}=$ (total dry matter obtained in treatment omitted nutrient / total dry matter obtained in the complete treatment $) \times 100$. The purpose of this procedure is to compare the total dry matter in the treatment with application of micronutrient compared to treatment where the micronutrient was not applied.

Data were submitted to analysis of variance and means were compared by the of Scott \& Knott test at $5 \%$.

\section{RESULTS AND DISCUSSION}

Banana seedlings Prata Anã and BRS Platina hybrid cultivars cultured in complete solution grew normally showing no visual symptoms of deficiency, indicating that the nutrient solution and $\mathrm{pH}$ used were appropriate for the growth of plants. In this treatment, it was observed that Prata Anã genotype had better performance than BRS Platina genotype for all variables (Table 1).

When submitted to B omission in the nutrient solution, genotypes did not differ regarding leaf area (LA), leaf dry matter (MSF), shoot dry matter (MSPA), root dry matter (MSR) and total dry matter (MSTO). However, the rhizome dry weight (MSRI) was higher in Prata Anã genotype (Table 1). Thus, it was found that the relative growth of banana seedlings was reduced by $94 \%$ for Prata Anã cultivar and $91 \%$ for BRS Platina hybrid cultivar, when under $\mathrm{B}$ deficiency conditions (Figure 1).

Most of the B functions in plants are related to cell wall formation and stabilization, lignification and differentiation of xylem and B plays a regulatory role in the metabolism of carbohydrates, facilitating their transportation from leaves to other organs (MIWA; FUJIWARA, 2010), acting on cell elongation, nucleic acid synthesis, hormonal responses (GONZÁLEZFONTES et al., 2008).

It was observed that Prata Anã genotype had better performance than BRS Platina genotype in the of MSF, DMAP, MSR, and MSTO and LA production using $\mathrm{Cu}$ and $\mathrm{Mn}$-deficient solution (Table 1). In treatments with omission of $\mathrm{Cu}$, relative growth showed a decrease of $47 \%$ in Prata Anã genotype and $87 \%$ in the BRS Platina hybrid genotype, and $84 \%$ in Prata Anã genotype and $86 \%$ in BRS Platina genotype when the Mn was omitted (Figure 1).

Copper is a micronutrient required for proper plant development, as plants with deficiency or excess of this micronutrient have reduced leaf area, also playing a role in the synthesis of proteins and metabolism of carbohydrates (Khurana et al., 2006). Manganese promotes significant effects on plant nutrition, both in the deficiency point of view, as in toxicity, with significant losses in the production of plants grown under both effects (Ferreira et al., 2009).

The lack of Fe affected more intensely the growth of BRS Platina hybrid, with lower LA, MSRI, MSF, MSPA and MSTO values, with no differences between genotypes only for MSR variable (Table 1). By comparing the growth of plants receiving complete treatments with treatments under omission of micronutrients, there is a reduction of $67 \%$ in the growth of Prata Anã genotype and $80 \%$ of BRS Platina genotype (Figure 1).

Iron, in plants, is related to various metabolic activities, participating in the formation of some enzymes (catalase, peroxidase, cytochrome oxidase and xanthine oxidase), and is essential in the breathing process, photosynthesis, $\mathrm{N}_{2}$ fixation and electron transfer through cycling between $\mathrm{Fe}^{2}+$ and $\mathrm{Fe}^{3}+$ (MORRISSEY; GUERIONOT, 2009).

When submitted will Zn omission, seedlings had lower production of MSPA, MSR, MSTO and LA in both genotypes (Table 1). The deficiency of this nutrient reduced the relative growth by $83 \%$ in Prata Anã and $77 \%$ in BRS Platina (Figure 1).

$\mathrm{Zn}$ deficiency contributed to a lower production of MSR, MSPA, MSTO and reduced LA of BRS Platina genotype compared to Prata 
Anã genotype (Table 1). The deficiency of this micronutrient reduced the relative growth by $83 \%$ for Prata Anã and 77\% for BRS Platina (Figure 1). This reduction occurs because $\mathrm{Zn}$ deficiency compromises major physiological events and, consequently, plant growth and development (Sadeghzadeh et al., 2013). $\mathrm{Zn}$ is an essential micronutrient for plant growth and under deficiency conditions, protein synthesis is dramatically reduced (due to the relationship with RNAase activity); causes delay and reduction in plant growth; small and poorly shaped leaves; short internodes; formation of leaves in rosettes; internerval chlorosis (due to the involvement of $\mathrm{Zn}$ in chlorophyll formation), and necrosis at the apical root meristem (Broadley et al., 2007).

Banana seedlings grown in nutrient solution with the omission of $\mathrm{B}, \mathrm{Cu}, \mathrm{Fe}, \mathrm{Mn}$ and $\mathrm{Zn}$ presented lower levels of these micronutrients compared to plants grown in complete solution, regardless of genotype or plant part, and only the omission of $\mathrm{Mn}$ did not result in a smaller rhizome content of BRS Platina genotype when compared to the complete treatment (Table 2). Bessa et al. (2013) found lower $\mathrm{B}, \mathrm{Cu}, \mathrm{Fe}, \mathrm{Mn}$ and $\mathrm{Zn}$ contents in mangabeira leaves under omission of these micronutrients in nutrient solution compared to complete treatment. Lange et al. (2005) working with castor bean Iris cultivar observed that the omission of $\mathrm{B}, \mathrm{Cu}, \mathrm{Fe}, \mathrm{Mn}, \mathrm{Mo}$ and $\mathrm{Zn}$ in the nutrient solution reduced their levels in tissues when compared with complete treatment.

B levels in leaves and roots in treatments where the micronutrient was omitted were the same for both banana genotypes; however, in the rhizome, although not differing between genotypes, B levels were lower when compared to other plant organs (Table 2). However, complete treatment showed no significant difference in the content of this nutrient in the different plant organs, as well as between the two banana genotypes.

When $\mathrm{Cu}$ was suppressed in the nutrient solution, there was no significant difference in the content of this micronutrient in the evaluated organs, regardless of genotype. In the complete treatment for Prata Anã cultivar, there was no difference in the $\mathrm{Cu}$ content in the different plant organs; however, in the BRS Platina hybrid cultivar, the highest $\mathrm{Cu}$ content occurred in the roots and the lowest in leaves. Prata Anã and BRS Platina hybrid genotypes differed only regarding the $\mathrm{Cu}$ content in the roots and in the complete treatment, where lower $\mathrm{Cu}$ levels were observed in Prata Anã cultivar (Table 2).

In treatments with $\mathrm{Fe}$ omission, there was no difference in the content of this micronutrient in the organs of banana seedlings between genotypes. In the complete treatment, $\mathrm{Fe}$ focused more on roots in Prata Anã cultivar and roots and leaves in the hybrid cultivar.

The banana seedlings of Prata Anã genotype grown in complete treatment showed higher $\mathrm{Mn}$ content in all organs when compared to BRS Platina hybrid, with no difference in content among plant organs (Table 2). As for the BRS Platina hybrid, Mn content was observed on the leaves. When in the absence of the micronutrient, it appears that there was difference only for the content of this micronutrient in roots and rhizome, verified for BRS platina hybrid genotype.

$\mathrm{Zn}$ levels in treatments with deficiency of this element were higher in leaves and roots for Prata Anã genotype and in rhizome and roots for BRS Platina genotype. BRS Platina genotype had higher Fe content compared to Prata Anã genotype in rhizome and roots, under omission of this nutrient. In treatments with adequate $\mathrm{Zn}$ supply, seedlings of BRS Platina and Prata Anã showed higher Zn content in leaves, but with superiority in BRS Platina genotype. Zinc activity is related to various metabolic processes due to its function as an enzyme activator, being essential for activity, regulation and stabilization of the protein structure (Broadley et al., 2007).

The total accumulation of micronutrients in Prata Anã cultivar in complete treatment had the following descending order: leaf $(64.31 \%)>$ root $(24.18 \%)>$ rhizome $(11.51 \%)$ and in BRS Platina hybrid, the descending order was leaf $(66.51 \%)>$ root $(18.85 \%)>$ rhizome $(14.64 \%)$ (Table 3$)$. As for the percentage distribution of micronutrient accumulation in roots and shoots of seedlings, with respect to the total accumulated in the plant, it was observed that all nutrients were accumulated in greater amounts in shoots, and Fe was the most absorbed micronutrient. Prata Anã cultivar was higher than the hybrid cultivar in the accumulation of all micronutrients.

The accumulation of micronutrients decreased in the following order $\mathrm{Fe}>\mathrm{Mn}>\mathrm{Zn}>\mathrm{B}>\mathrm{Cu}$ for both banana genotypes, reflecting the plant requirements (Table 3). Hoffmann et al. (2010) worked with six banana varieties and found that the accumulation of micronutrients depends on the cultivar or genotype and Rodrigues et al. (2010) found the same requirement order for Prata Anã mother plants.

Varieties more efficient in the acquisition of nutrients in soils with low levels are generally considered better adapted to such conditions. The variations in the acquisition of soil nutrients can be attributed to factors related to the function and 
structure of the root system, including morphological characteristics and biochemical mechanisms responsible for the transfer of ions in cell membranes of roots (KHOSHGOFTARMANESH et al., 2010). Treatments differed on the absorption efficiency (AE) of micronutrients, verifying higher uptake rate by plants grown in complete treatment (Table 4). Under this condition, BRS Platina hybrid was more efficient in the absorption of $\mathrm{B}, \mathrm{Fe}$ and $\mathrm{Zn}$ and Prata Anã cultivar in the absorption of Mn; for $\mathrm{Cu}$, no difference between genotypes was observed. In treatments with omission of micronutrients, no difference in $\mathrm{AE}$ between genotypes for $\mathrm{B}, \mathrm{Cu}$ and $\mathrm{Zn}$, and Prata Anã cultivar presented higher AE for $\mathrm{Fe}$ and BRS Platina for Mn.

The differences between the banana genotypes regarding the ability to absorb micronutrient derive both from the variation in the morphology of the root system and the nutrient absorption kinetics. Variations in the morphological root parameters (extensive and efficient root system) and absorption kinetics (Vmax, $\mathrm{Km}$ and $\mathrm{Cmin}$ ) are required to operate the models that quantitatively describe the process of nutrient absorption (MAATHUIS; DIATLOFF, 2013; CHRISTO et al., 2014; MARTINS et al, 2015).

Considering transport efficiency (TE) as the plant's ability to transport nutrients from roots to shoots, it was observed that in treatment with adequate supply of micronutrients, BRS Platina cultivar showed higher TE for Fe and $\mathrm{Mn}$, and Prata Anã cultivar had higher TE for $\mathrm{Cu}$ and there was no difference in TE for B and $\mathrm{Zn}$ (Table 4). Under omission of micronutrients, Prata Anã cultivar had higher TE for $\mathrm{B}, \mathrm{Cu}$ and $\mathrm{Fe}$ and BRS Platina cultivar for $\mathrm{Mn}$ and no difference for $\mathrm{Zn}$ was observed. Translocation of micronutrients from roots to shoots via xylem is conducted either through transpiration or root pressure and rarely is a limiting step (Sadeghzadeh et al., 2013), and the difference between banana genotypes can be related to morphological differences in the configuration of vascular elements.

The utilization efficiency (UE) is defined as the capacity of utilization of nutrients for synthesis of dry matter mass. The efficiency in the use of nutrient absorbed by the plant is as important as the absorption efficiency when evaluating the dry matter mass production with respect to nutrient supply (POZZA et al., 2009). According to the mean values, it was observed that regardless of the concentration of nutrients in the nutrient solution, Prata Anã cultivar showed higher UE of all micronutrients (Table 4), with greater dry matter mass production (Table 1). This results found for Prata Anã cultivar is interesting, since banana responds well in productivity when well supplied in micronutrients, especially zinc and boron (HOFFMANN et al, 2010; RODRIGUES et al., 2010). This result highlights the potential of this cultivar for growing in soils with low content of these micronutrients, since this condition is common in Cerrado soils.

The use of increasingly concentrated fertilizers, increased yields and the intensive use of soils may cause over time, the appearance of micronutrient deficiencies in banana. Among micronutrients, the most common deficiencies in banana crop are B and Zn (SILVA; RODRIGUES, 2001), but depending on the soil, deficiencies of other micronutrients may appear.

The nutrient use efficiency may vary within the same plant species according to the genotypic differences that may occur in genotype-environment interactions and may also be related to the demand of nutrients at cell level, compartmentalization, use in shoots, transport at short and long distance, in affinity of the absorption system (Km), minimum concentration ( $\mathrm{C}$ min) and in changes in the rhizosphere. These differences can change the absorption capacity, transport and utilization of nutrients by plants (CHRISTO et al, 2014; MARTINS et al, 2015). 
TABLE 1 - Leaf area (LA), dry matter mass production of rhizome (MSRI), leaves (MSF), shoots (MSPA), roots (MSR) and total (MSTO) of two banana genotypes: Prata Anã and BRS Platina hybrid with complete solution and diagnosis by subtraction of micronutrients.

\begin{tabular}{|c|c|c|c|c|c|}
\hline \multirow[t]{2}{*}{ Variable } & \multicolumn{2}{|c|}{ Prata-Anã } & \multicolumn{2}{|c|}{ BRS Platina } & \multirow[t]{2}{*}{$\mathrm{VC}(\%)$} \\
\hline & Complete & Omission & Complete & Omission & \\
\hline \multicolumn{6}{|c|}{ 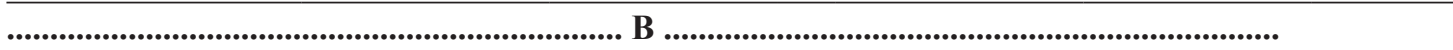 } \\
\hline $\mathrm{AF}\left(\mathrm{cm}^{2}\right)$ & $1710.39 \mathrm{a}$ & $14.44 \mathrm{c}$ & $568.93 \mathrm{~b}$ & $16.52 \mathrm{c}$ & 3.57 \\
\hline MSRI (g plant $\left.{ }^{-1}\right)$ & $2.61 \mathrm{a}$ & $0.61 \mathrm{c}$ & $1.31 \mathrm{~b}$ & $0.21 \mathrm{~d}$ & 6.63 \\
\hline MSF $\left(\right.$ g plant $\left.^{-1}\right)$ & $11.47 \mathrm{a}$ & $0.18 \mathrm{c}$ & $4.07 \mathrm{~b}$ & $0.14 \mathrm{c}$ & 11.41 \\
\hline $\operatorname{MSR}\left(g_{\text {plant }}^{-1}\right)$ & $4.35 \mathrm{a}$ & $0.31 \mathrm{c}$ & $1.43 \mathrm{~b}$ & $0.24 \mathrm{c}$ & 9.31 \\
\hline $\operatorname{MSPA}\left(\mathrm{g} \mathrm{plant}^{-1}\right)$ & $14.08 \mathrm{a}$ & $0.78 \mathrm{c}$ & $5.38 \mathrm{~b}$ & $0.36 \mathrm{c}$ & 9.78 \\
\hline $\operatorname{MSTO}\left(\mathrm{g}_{\text {plant }}{ }^{-1}\right)$ & $18.43 \mathrm{a}$ & $1.10 \mathrm{c}$ & $6.80 \mathrm{~b}$ & $0.60 \mathrm{c}$ & 9.66 \\
\hline \multicolumn{6}{|c|}{ (n) } \\
\hline $\mathrm{AF}\left(\mathrm{cm}^{2}\right)$ & $1710.39 \mathrm{a}$ & $575.89 \mathrm{~b}$ & $568.93 \mathrm{~b}$ & $36.96 \mathrm{c}$ & 7.10 \\
\hline MSRI (g plant ${ }^{-1}$ ) & $2.61 \mathrm{a}$ & $2.34 \mathrm{a}$ & $1.31 \mathrm{~b}$ & $0.42 \mathrm{c}$ & 17.74 \\
\hline $\operatorname{MSF}\left(\right.$ g plant $\left.^{-1}\right)$ & $11.47 \mathrm{a}$ & $6.00 \mathrm{~b}$ & $4.07 \mathrm{~b}$ & $0.28 \mathrm{c}$ & 14.10 \\
\hline $\operatorname{MSR}\left(g_{\text {plant }}^{-1}\right)$ & $4.35 \mathrm{a}$ & $1.50 \mathrm{~b}$ & $1.43 \mathrm{~b}$ & $0.22 \mathrm{c}$ & 19.27 \\
\hline MSPA $\left(g_{\text {plant }}^{-1}\right)$ & $14.08 \mathrm{a}$ & $8.34 \mathrm{~b}$ & $5.38 \mathrm{c}$ & $0.69 \mathrm{~d}$ & 21.80 \\
\hline MSTO $\left(\mathrm{g}_{\text {plant }}{ }^{-1}\right)$ & $18.43 \mathrm{a}$ & $9.84 \mathrm{~b}$ & $6.80 \mathrm{c}$ & $0.91 \mathrm{~d}$ & 19.16 \\
\hline \multicolumn{6}{|c|}{ (n) } \\
\hline $\mathrm{AF}\left(\mathrm{cm}^{2}\right)$ & $1710.39 \mathrm{a}$ & $605.91 \mathrm{~b}$ & $568.93 \mathrm{c}$ & $45.70 \mathrm{~d}$ & 2.83 \\
\hline MSRI (g plant $\left.{ }^{-1}\right)$ & $2.61 \mathrm{a}$ & $1.06 \mathrm{~b}$ & $1.31 \mathrm{~b}$ & $0.43 \mathrm{c}$ & 16.44 \\
\hline MSF (g plant $\left.{ }^{-1}\right)$ & $11.47 \mathrm{a}$ & $4.13 \mathrm{~b}$ & $4.07 \mathrm{~b}$ & $0.37 \mathrm{c}$ & 9.21 \\
\hline $\operatorname{MSR}\left(g_{\text {plant }}^{-1}\right)$ & $4.35 \mathrm{a}$ & $0.87 \mathrm{c}$ & $1.43 \mathrm{~b}$ & $0.54 \mathrm{c}$ & 13.16 \\
\hline $\operatorname{MSPA}\left(\mathrm{g}\right.$ plant $\left.{ }^{-1}\right)$ & $14.08 \mathrm{a}$ & $5.19 \mathrm{~b}$ & $5.38 \mathrm{~b}$ & $0.81 \mathrm{c}$ & 10.14 \\
\hline $\operatorname{MSTO}\left(\mathrm{g}_{\text {plant }}{ }^{-1}\right)$ & $18.43 \mathrm{a}$ & $6.05 \mathrm{~b}$ & $6.80 \mathrm{~b}$ & $1.35 \mathrm{c}$ & 12.57 \\
\hline \multicolumn{6}{|c|}{ (1) } \\
\hline $\mathrm{AF}\left(\mathrm{cm}^{2}\right)$ & $1710.39 \mathrm{a}$ & $288.74 \mathrm{c}$ & $568.93 \mathrm{~b}$ & $33.34 \mathrm{~d}$ & 11.25 \\
\hline MSRI (g plant $\left.{ }^{-1}\right)$ & $2.61 \mathrm{a}$ & $0.84 \mathrm{c}$ & $1.31 \mathrm{~b}$ & $0.43 \mathrm{~d}$ & 6.63 \\
\hline MSF $\left(g_{\text {plant }}^{-1}\right)$ & $11.47 \mathrm{a}$ & $1.62 \mathrm{c}$ & $4.07 \mathrm{~b}$ & $0.28 \mathrm{~d}$ & 12.22 \\
\hline $\operatorname{MSR}\left(g_{\text {plant }}^{-1}\right)$ & $4.35 \mathrm{a}$ & $0.57 \mathrm{c}$ & $1.43 \mathrm{~b}$ & $0.23 \mathrm{~d}$ & 11.22 \\
\hline MSPA $\left(\right.$ g plant $\left.^{-1}\right)$ & $14.08 \mathrm{a}$ & $2.45 \mathrm{c}$ & $5.38 \mathrm{~b}$ & $0.71 \mathrm{~d}$ & 10.82 \\
\hline MSTO $\left(\mathrm{g}_{\text {plant }}{ }^{-1}\right)$ & $18.43 \mathrm{a}$ & $3.03 \mathrm{c}$ & $6.80 \mathrm{~b}$ & $0.94 \mathrm{~d}$ & 10.89 \\
\hline \multicolumn{6}{|c|}{ 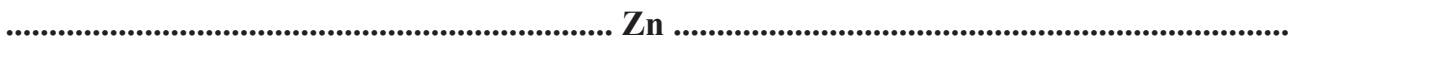 } \\
\hline $\mathrm{AF}\left(\mathrm{cm}^{2}\right)$ & 1710.39 a & $110.38 \mathrm{c}$ & $568.93 \mathrm{~b}$ & $42.92 \mathrm{~d}$ & 6.42 \\
\hline MSRI (g plant $\left.{ }^{-1}\right)$ & $2.61 \mathrm{a}$ & $0.58 \mathrm{c}$ & $1.31 \mathrm{~b}$ & $0.39 \mathrm{c}$ & 14.16 \\
\hline $\operatorname{MSF}\left(g_{\text {plant }}^{-1}\right)$ & $11.47 \mathrm{a}$ & $1.28 \mathrm{c}$ & $4.07 \mathrm{~b}$ & $0.51 \mathrm{c}$ & 15.70 \\
\hline $\operatorname{MSR}\left(g_{\text {plant }}^{-1}\right)$ & $4.35 \mathrm{a}$ & $1.21 \mathrm{~b}$ & $1.43 \mathrm{~b}$ & $0.66 \mathrm{c}$ & 10.18 \\
\hline MSPA $\left(g_{\text {plant }}^{-1}\right)$ & $14.08 \mathrm{a}$ & $1.87 \mathrm{c}$ & $5.38 \mathrm{~b}$ & $0.89 \mathrm{~d}$ & 14.15 \\
\hline $\operatorname{MSTO}\left(\mathrm{g}_{\text {plant }}{ }^{-1}\right)$ & $18.43 \mathrm{a}$ & $3.08 \mathrm{c}$ & $6.80 \mathrm{~b}$ & $1.56 \mathrm{~d}$ & 14.12 \\
\hline
\end{tabular}

Means followed by the same letter in the line do not differ between each variable evaluated by the Scott \& Knott test at $5 \%$. 


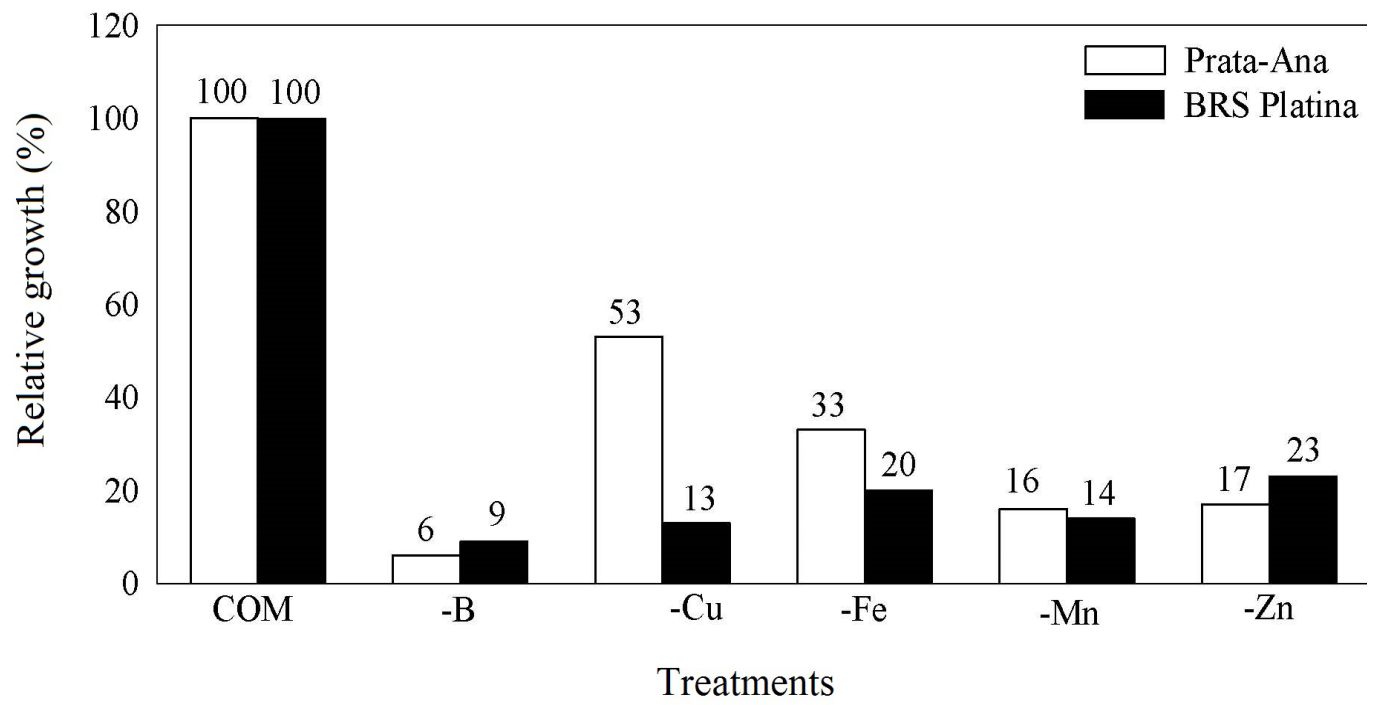

FIGURE 1 - Relative growth in total dry matter of two banana genotypes: Prata Anã and BRS Platina hybrid submitted to different fertilization treatments, as follows: COM (complete solution); -B (B omission); - $\mathrm{Cu}$ (Cu omission); - $\mathrm{Fe}$ (Fe omission); -Mn (Mn omission) and $\mathrm{Zn}$ (Zn omission).

TABLE 2 - Content of micronutrients of two banana genotypes: Prata Anã and BRS Platina hybrid with complete solution and diagnosis by subtraction of micronutrients in different plant parts.

\begin{tabular}{|c|c|c|c|c|}
\hline \multirow[t]{2}{*}{ Plant part } & \multicolumn{2}{|c|}{ Prata-Anã } & \multicolumn{2}{|c|}{ BRS Platina } \\
\hline & Complete & Omission & Complete & Omission \\
\hline & \multicolumn{4}{|c|}{$\mathrm{B}\left(\mathrm{mg} \mathrm{kg}^{-1}\right)-\mathrm{VC}=16.92 \%$} \\
\hline Leaves & $18.27 \mathrm{aA}$ & $1.78 \mathrm{bA}$ & $18.16 \mathrm{aA}$ & $1.12 \mathrm{bA}$ \\
\hline Rhizome & $18.78 \mathrm{aA}$ & $0.04 \mathrm{bB}$ & $17.49 \mathrm{aA}$ & $0.08 \mathrm{bB}$ \\
\hline \multirow[t]{2}{*}{ Roots } & $18.12 \mathrm{aA}$ & $0.95 \mathrm{bA}$ & $19.01 \mathrm{aA}$ & $0.95 \mathrm{bA}$ \\
\hline & \multicolumn{4}{|c|}{$\mathrm{Cu}(\mathrm{mg} \mathrm{kg}-1)-\mathrm{VC}=17.24 \%$} \\
\hline Leaves & $8.29 \mathrm{aA}$ & $0.55 \mathrm{bA}$ & $6.58 \mathrm{aC}$ & $1.97 \mathrm{bA}$ \\
\hline Rhizome & $10.02 \mathrm{aA}$ & $0.54 \mathrm{bA}$ & $9.23 \mathrm{aB}$ & $0.84 \mathrm{bA}$ \\
\hline \multirow[t]{2}{*}{ Roots } & $8.95 \mathrm{bA}$ & $0.74 \mathrm{cA}$ & $14.44 \mathrm{aA}$ & $2.70 \mathrm{cA}$ \\
\hline & \multicolumn{4}{|c|}{$\mathrm{Fe}\left(\mathrm{mg} \mathrm{kg}^{-1}\right)-\mathrm{VC}=15.18 \%$} \\
\hline Leaves & $104.77 \mathrm{bB}$ & $12.14 \mathrm{cA}$ & $129.46 \mathrm{aA}$ & $15.11 \mathrm{cA}$ \\
\hline Rhizome & $88.79 \mathrm{bC}$ & $16.37 \mathrm{cA}$ & $109.86 \mathrm{aB}$ & $15.56 \mathrm{cA}$ \\
\hline \multirow[t]{2}{*}{ Roots } & $140.02 \mathrm{aA}$ & $14.85 \mathrm{cA}$ & $124.49 \mathrm{bA}$ & $8.35 \mathrm{cA}$ \\
\hline & \multicolumn{4}{|c|}{$\mathrm{Mn}\left(\mathrm{mg} \mathrm{kg}^{-1}\right)-\mathrm{VC}=21.74 \%$} \\
\hline Leaves & $97.75 \mathrm{aA}$ & $3.03 \mathrm{dA}$ & $66.55 \mathrm{bA}$ & $21.99 \mathrm{cA}$ \\
\hline Rhizome & $61.18 \mathrm{aB}$ & $4.39 \mathrm{cA}$ & $9.52 \mathrm{bC}$ & $7.85 \mathrm{bB}$ \\
\hline \multirow[t]{2}{*}{ Roots } & $64.01 \mathrm{aB}$ & $2.95 \mathrm{cA}$ & $22.36 \mathrm{bB}$ & $5.89 \mathrm{cB}$ \\
\hline & \multicolumn{4}{|c|}{$\mathrm{Zn}\left(\mathrm{mg} \mathrm{kg}^{-1}\right)-\mathrm{VC}=7.85 \%$} \\
\hline Leaves & $22.46 \mathrm{bA}$ & $1.15 \mathrm{cA}$ & $26.61 \mathrm{aA}$ & $0.97 \mathrm{cB}$ \\
\hline Rhizome & $18.97 \mathrm{aB}$ & $0.34 \mathrm{cB}$ & $18.84 \mathrm{aB}$ & $1.83 \mathrm{bA}$ \\
\hline Roots & $18.19 \mathrm{aB}$ & $1.53 \mathrm{dA}$ & $16.02 \mathrm{bC}$ & $2.24 \mathrm{cA}$ \\
\hline
\end{tabular}

Means followed by the same letters, small in lines and capital in columns do not differ by the Scott \& Knott test at $5 \%$. 
TABLE 3 - Accumulated amount of micronutrient of two banana genotypes: Prata Anã and BRS Platina hybrid with a complete solution in different plant parts.

\begin{tabular}{|c|c|c|c|c|c|c|}
\hline Micronutrient & Genotype & Leaf & Rhizome & Roots & Total & $\mathrm{VC}(\%)$ \\
\hline & & & $\ldots \ldots \ldots . . . \mu \mathrm{g}$ & & & \\
\hline \multirow[t]{2}{*}{ B } & Prata-Anã & $209.48 \mathrm{aA}$ & $49.03 \mathrm{cA}$ & $78.81 \mathrm{bA}$ & 337.32 & \\
\hline & BRS Platina & $71.55 \mathrm{aB}$ & $22.89 \mathrm{bB}$ & $26.12 \mathrm{bB}$ & 120.56 & 11.66 \\
\hline \multirow[t]{2}{*}{$\mathrm{Cu}$} & Prata-Anã & $95.01 \mathrm{aA}$ & $26.16 \mathrm{cA}$ & $38.92 \mathrm{bA}$ & 160.09 & \\
\hline & BRS Platina & $26.08 \mathrm{aB}$ & $11.78 \mathrm{cB}$ & $19.16 \mathrm{bB}$ & 57.02 & 7.40 \\
\hline \multirow[t]{2}{*}{$\mathrm{Fe}$} & Prata-Anã & $1201.28 \mathrm{aA}$ & $231.78 \mathrm{cA}$ & $609.20 \mathrm{bA}$ & 2042.27 & \\
\hline & BRS Platina & $502.45 \mathrm{aB}$ & $143.93 \mathrm{bB}$ & $177.49 \mathrm{bB}$ & 823.87 & 8.47 \\
\hline \multirow[t]{2}{*}{ Mn } & Prata-Anã & $1120.83 \mathrm{aA}$ & $159.70 \mathrm{cA}$ & $278.51 \mathrm{bA}$ & 1559.04 & \\
\hline & BRS Platina & $270.71 \mathrm{aB}$ & $12.47 \mathrm{cB}$ & $31.88 \mathrm{bB}$ & 315.06 & 18.52 \\
\hline \multirow[t]{2}{*}{$\mathrm{Zn}$} & Prata-Anã & $257.51 \mathrm{aA}$ & $49.53 \mathrm{cA}$ & $79.14 \mathrm{bA}$ & 386.18 & \\
\hline & BRS Platina & $108.92 \mathrm{aB}$ & $24.68 \mathrm{bB}$ & $22.84 \mathrm{bB}$ & 156.45 & 13.71 \\
\hline
\end{tabular}

Means followed by the same letters, small in lines and capital in columns do not differ by the Scott \& Knott test at $5 \%$.

TABLE 4-Absorption and transport efficiency and use of micronutrients by two banana genotypes: Prata Anã and BRS Platina hybrid with complete solution and diagnosis by subtraction of micronutrients.

\begin{tabular}{|c|c|c|c|c|c|}
\hline \multirow[t]{2}{*}{ Micronutrient } & \multicolumn{2}{|c|}{ Prata-Anã } & \multicolumn{2}{|c|}{ BRS Platina } & \multirow[t]{2}{*}{$\mathrm{VC}(\%)$} \\
\hline & Complete & Omission & Complete & Omission & \\
\hline \multicolumn{6}{|c|}{ Absorption efficiency } \\
\hline & ....... mg & ent $g^{-1}$ root $d r$ & .................... & & \\
\hline B & $77.53 \mathrm{~b}$ & $2.04 \mathrm{c}$ & $87.00 \mathrm{a}$ & $1.69 \mathrm{c}$ & 18.10 \\
\hline $\mathrm{Cu}$ & $36.80 \mathrm{a}$ & $3.80 \mathrm{~b}$ & $42.21 \mathrm{a}$ & $6.78 \mathrm{~b}$ & 18.27 \\
\hline $\mathrm{Fe}$ & $469.41 \mathrm{~b}$ & $184.11 \mathrm{c}$ & $594.69 \mathrm{a}$ & $31.37 \mathrm{~d}$ & 15.81 \\
\hline $\mathrm{Mn}$ & $358.34 \mathrm{a}$ & $18.29 \mathrm{~d}$ & $220.62 \mathrm{~b}$ & $44.47 \mathrm{c}$ & 18.34 \\
\hline $\mathrm{Zn}$ & $88.76 \mathrm{~b}$ & $2.68 \mathrm{c}$ & $109.47 \mathrm{a}$ & $4.01 \mathrm{c}$ & 14.30 \\
\hline \multirow{2}{*}{\multicolumn{6}{|c|}{ Transport efficiency }} \\
\hline & & & & & \\
\hline B & $76.56 \mathrm{a}$ & $53.50 \mathrm{~b}$ & $78.30 \mathrm{a}$ & $43.90 \mathrm{c}$ & 5.76 \\
\hline $\mathrm{Cu}$ & $75.69 \mathrm{~b}$ & $80.84 \mathrm{a}$ & $66.74 \mathrm{c}$ & $60.10 \mathrm{c}$ & 3.60 \\
\hline $\mathrm{Fe}$ & $70.14 \mathrm{c}$ & $88.23 \mathrm{a}$ & $78.58 \mathrm{~b}$ & $73.58 \mathrm{c}$ & 4.60 \\
\hline $\mathrm{Mn}$ & $81.17 \mathrm{~b}$ & $83.88 \mathrm{~b}$ & $89.86 \mathrm{a}$ & $86.64 \mathrm{a}$ & 2.70 \\
\hline $\mathrm{Zn}$ & $79.47 \mathrm{a}$ & $40.71 \mathrm{c}$ & $85.36 \mathrm{a}$ & $43.88 \mathrm{c}$ & 8.73 \\
\hline \multirow{2}{*}{\multicolumn{6}{|c|}{$\begin{array}{l}\text { Use efficiency } \\
\mathrm{g} \mathrm{mg}^{-1} \text { accumulated nutrient }\end{array}$}} \\
\hline & & & & & \\
\hline B & $1.01 \mathrm{~b}$ & $1.87 \mathrm{a}$ & $0.39 \mathrm{c}$ & $0.89 \mathrm{~b}$ & 16.01 \\
\hline $\mathrm{Cu}$ & $2.12 \mathrm{~b}$ & $6.30 \mathrm{a}$ & $0.87 \mathrm{c}$ & $0.57 \mathrm{c}$ & 10.43 \\
\hline $\mathrm{Fe}$ & $0.17 \mathrm{~b}$ & $0.52 \mathrm{a}$ & $0.06 \mathrm{c}$ & $0.11 \mathrm{c}$ & 11.09 \\
\hline Mn & $0.23 \mathrm{~b}$ & $0.89 \mathrm{a}$ & $0.15 \mathrm{c}$ & $0.09 \mathrm{c}$ & 13.28 \\
\hline $\mathrm{Zn}$ & $0.88 \mathrm{~b}$ & $2.81 \mathrm{a}$ & $0.30 \mathrm{c}$ & $0.90 \mathrm{~b}$ & 17.04 \\
\hline
\end{tabular}

Means followed by the same letter in line do not differ between each variable evaluated by the Scott \& Knott test at $5 \%$. 


\section{CONCLUSIONS}

B deficiency intensely affected the growth of both genotypes. The accumulation of nutrients corresponds to the following descending order $\mathrm{Fe}>$ $\mathrm{Mn}>\mathrm{Zn}>\mathrm{B}>\mathrm{Cu}$, reflecting the requirements of Prata Anã and BRS Platina hybrid cultivars. BRS Platina hybrid showed higher absorption efficiency of $\mathrm{B}, \mathrm{Fe}$ and $\mathrm{Zn}$ in relation to Prata Anã cultivar that showed higher absorption efficiency of Mn. BRS Platina hybrid showed higher transport efficiency of $\mathrm{Fe}$ and Mn while Prata Anã cultivar only for $\mathrm{Cu}$. Prata Anã cultivar showed higher micronutrient use efficiency compared to BRS Platina hybrid.

\section{REFERENCES}

BESSA, L.A.; SILVA, F.G.; MOREIRA, M.A.; TEODORO, J.P.R.; SOARES, F.A.L. Characterization of nutrient deficiency in Hancornia speciose Gomes seedlings by omitting micronutrients from the nutrient solution. Revista Brasileira de Fruticultura, Jaboticabal, v.35, n.2, p.616-624, 2013.

BROADLEY, M.R.;WHITE, P.J.; HOMMOND, J.P.; ZELKO, I.; LUX, A. Zinc in plants. New Phytologist, Saint Paul, v.173, n.4, p.677-702, 2007.

CHRISTO, L.F.; MARTINS, L.D.; COLODETT, T.V.; RODRIGUES, W.N.; BRINATE, S.B.; AMARAL, J.F.T.; TOMAZ, M.A.; LAVIOLA, B.G. Differences between genotypes of Jatropha Curcas L. are evidenced for absorption and use of nitrogen. African Journal of Agricultural Research, Nairobi, v. 9, n. 26, p. 2085-2094, 2014.

FERREIRA, E.V.O.; CARVALHO, J.G.; JÚNIOR, L.A.F.; BASTOS, A.R.R.; PINHO, P.J. Manganês na nutrição mineral de cultivares de arroz de terras altas. Pesquisa Agropecuária Tropical, Goiânia, v.39, n.2, p.151-157, 2009.

FERREIRA, O.G.L.; ROSSI, F.D.;ANDRIGHETTO, C. DDA: software para determinação de área foliar, índice de área foliar e área de olho de lombo - versão 1.2. Santo Augusto: IFFarroupilha, 2008.
GONZÁLEZ-FONTES, A.; REXACH, J.; NAVARRO-GOCHICOA, M.; HERRERARODRÍGUEZ, M.; BEATO, V.; MALDONADO, J.; CAMACHO-CRISTÓBAL, J. Is boron involved solely in structural roles in vascular plants? Plant Signaling \& Behavior, Bethesda, v.3, n.1, p.24-26, 2008.

HOAGLAND, D.R.; ARNON, D.I. The water culture method for growing plants without soils. Berkeley: California Agricultural Experimental Station, 1950.

HOFFMANN, R.B.; OLIVEIRA, F.H.T.; GHEYI, H.R.; SOUZA, A.P.; ARRUDAS, J.A. Acúmulo de matéria seca, absorção e exportação de micronutrientes em variedades de bananeira sob irrigação. Ciência e Agrotecnologia, Lavras, v.34, n.3, p.536-544, 2010.

IBGE. Instituto Brasileiro de Geografia e Estatística. Levantamento sistemático da produção agrícola. Rio de Janeiro: IBGE, 2012. 88p.

KHOSHGOFTARMANESH, A.H.; SCHULIN, R.; CHANEY, R.L.; DANESHBAKHSH, B.; AFYUNI, $M$. Micronutrient-efficient genotypes for crop yield and nutritional quality in sustainable agriculture. A review. Agronomy For Sustainable Development, Paris, v. 30, n. 1, p.83-107, 2010.

KHURANA, N.; SINGH, M. V.; CHATTERJEE, C. Copper stress alters physiology and deteriorates seed quality of rapeseed. Journal of Plant Nutrition, New York, v. 29, n. 1, p. 93-101, 2006.

LANGE, A.; MARTINES, A.M.; SILVA, M.A.C.; SORREANO, M.C.M.; CABRAL, C.P.; MALAVOLTA, E. Deficiências de micronutrientes no estado nutricional da mamoneira cultivar Íris. Pesquisa Agropecuária Brasileira, Brasília, v.40, n.1, p.61-67, 2005.

LI, B.; McKEAND, S.E.; ALLEN, H.L. Genetic variation in nitrogen use efficiency of loblolly pine seedlings. Forest Science, Bethesda, v.37, n.2, p.613-626, 1991.

MAATHUIS, F.J.; DIATLOFF, E. Roles and functions of plant mineral nutrients. In: MAATHUIS, F.J. (Ed.). Plant mineral nutrients: methods and protocols. Totowa: Humana Press, 2013. cap. 1, p. $1-21$. 
MARTINS, L.D.; MACHADO, L.S.; TOMAZ, M.A.; AMARAL, J.F.T. The nutritional efficiency of Coffea ssp. A review. African Journal of Biotechnology, Nairobi, v. 14, n. 9, p. 728-734, 2015.

MIWA, K.; FUJIWARA, T. Boron transport in plants: co-ordinated regulation of transporters. Annals of Botany, London, v.105, n.7, p.1103-1108, 2010.

MORRISSEY, J.; GUERIONOT, M.L. Iron uptake and transport in plants: the good, the bad, and the ionome. Chemical Reviews, Washington, v. 109, n.10, p. 4553-4567, 2009.

POZZA, A.A.A.; CARVALHO, J.G.; GONTIJO, P.T.; FIGUEIREDO, F.C.; ARAÚJO, A.R. Suprimento do silicato de cálcio e a eficiência nutricional de variedades de cafeeiro. Revista Brasileira de Ciência do Solo, Viçosa, MG, v.33, n.6, p.17051714, 2009.

RODRIGUES, M.G.V.; PACHECO, D.D.; NATALE, W.; SILVA, J.T.A.; DIAS, M.S.C. Distribuição da biomassa e minerais em "família" de bananeira 'prata-anã' adubada com zinco via broto desbastado. Revista Brasileira de Fruticultura, Jaboticabal, v. 32, n. 2, p. 599-611, 2010.
SADEGHZADEH, B. A review of zinc nutrition and plant breeding. Journal of Soil Science and Plant Nutrition, Santiago, v.13, n.4, p. 905-927, 2013.

SIDDQI, M.Y.; GLASS, A.D.M. Utilization index: a modified approach to the estimation and comparison of nutrient efficiency in plants. Journal of Plant Nutrition, New York, v.4, n.3, p.289-302, 1981.

SILVA, E.B.; RODRIGUES, M.G.L. Levantamento nutricional dos bananais da região Norte de Minas Gerais pela análise foliar. Revista Brasileira de Fruticultura, Jaboticabal, v.23, n.3, p.695-698, 2001.

SILVA, F. C. Manual de análises químicas de solos, plantas e fertilizantes. 2.ed. Brasília: Embrapa Informações Tecnológicas, 2009. 627 p.

SWIADER, J.M.; CHYAN, Y.; FREIJI, F.G. Genotypic differences in nitrate uptake and utilization efficiency in pumpkin hybrids. Journal of Plant Nutrition, New York, v.17, n.10, p.1687-1699, 1994. 